\title{
散水中の木材クリブ燃焼の発熱速度と放射熱流束の関係に関する研究 A STUDY ON RELATION BETWEEN HEAT RELEASE RATE AND RADIATIVE HEAT FLUX OF WOOD CRIB BURNING DURING WATER DISCHARGE
}

\author{
砂原弘幸*, 石原慶大**, 松山 賢***, 菅原進一 $* * * *$, 森田昌宏***** \\ Hiroyuki SUNAHARA, Takahiro ISHIHARA, Ken MATSUYAMA, \\ Shin ichi SUGAHARA and Masahiro MORITA
}

\begin{abstract}
Oxygen Consumption Calorimetric Method is generally used for measuring heat release rate (HRR) of combustible items. However, this method might have an uncertain result for gas concentration in case of during water discharged such as sprinkler.

In this study, we tried to find out an appropriate and simple method for measuring HRR during water discharged. A relation between HRR in free burning condition, which was calculated by mass loss rate, and radiative heat flux was obtained experimentally. The Mie theory was applied to estimate a radiative attenuation by the absorption of water droplet, because the radiative heat flux during water discharged needs to take it into account. As a result, the radiative attenuation calculated by the theory was verified by experimental data.
\end{abstract}

Keywords: Wood crib, Sprinkler, Heat release rate, Radiative heat flux, Water droplet, Mie scattering, 木材クリブ，スプリンクラー，発熱速度，放射熱流束，水滴，ミ一散乱

\section{1.はじめに}

多くの火災に対し、スプリンクラー設備に代表される水系消火設 備は有効な消火抑制手段であると認識されており、奏功事例も多々 報告されている1)。その有効性の評価は、散水中の発熱速度の変化 により行われることが最も的確であると考えられる。ところが散水 中の発熱速度の予測については、Evansによる(1)式が唯一の式であ

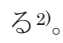

$$
\dot{Q}\left(t-t_{a c t}\right)=\dot{Q}\left(t_{a c t}\right) \cdot \exp \left\{-\left(t-t_{a c t}\right) / 3.0(\dot{w})^{-1.85}\right\}
$$

ここで、 $\dot{Q}$ : 発熱速度 $(\mathrm{kW}) 、 t_{a c t}$ : スプリンクラー作動時刻 $(\mathrm{s}) 、$ $t: t_{a c t}$ 以降の時刻 $(\mathrm{s}) 、 \dot{w}:$ 散水密度 $(\mathrm{mm} / \mathrm{s})$ である。

(1)式は、散水障害が無く、散布水量が $0.07 \mathrm{~mm} / \mathrm{s} \quad\left(4.2 \mathrm{~L} / \mathrm{min} \cdot \mathrm{m}^{2}\right)$ 以上の場合に適用可能であり、 $\left(t-t_{a c t}\right)$ が常に正で指数関数部分は 単調減少となる。したがって、例えば散水が十分ではないが発熱速 度の上昇速度を緩慢にしている場合のように、増加傾向に対しては 適用対象外となる久点もある。このような知見の少なさは、実験に 基づく散水時の燃焼発熱速度の測定事例が少ないことに起因する。 発熱速度の測定には多くの場合、酸素消費法または重量減少法が
用いられる。酸素消費法は燃焼物の上方に集煙フードを設け、燃焼 ガスを採取し、燃焼生成ガスの分析結果から発熱速度を計算する方 法である。しかし、散水を伴う場合、散水による気流の乱れと冷却 のためガスサンプリングに遅れと乱れが生じ、条件によっては発熱 速度の経時変化を得ることは困難となることが多い3)。また重量減 少法では、散水を行った場合、重量減少速度が可燃物が吸収した水 の重量の影響を受け、正確な発熱速度の值を求めることはできない。 このように、従来一般的に用いられている方法では散水中の発熱速 度を直接求めることが困難であるため、何らかの測定值からの間接 的な推測であっても、できる限り簡便かつ精度の高い測定方法の提 案が望まれる。本研究においては、スプリンクラーによる散水中の 放射熱流束の測定值から発熱速度を推測する方法に関して検討と提 案を行う。

放射熱流束は温度と同様に実験中に比較的簡便に測定可能な物理 量の一つであり、放射熱流束から散水中の発熱速度が推測可能であ れば、スプリンクラー設備の消火性能の定量的評価が可能となるだ けでなく、今後開発されるであろう新規水系消火設備との定量的性 能比較が可能となる。

\footnotetext{
* ヤマトプロテック/東京理科大学理工学研究科建築学専攻 修士(理学)

** ヤマトプロテック 修士 (工学)

*** 東京理科大学総合研究機構火災科学研究センター 准教授・博士 (工学)

**** 東京理科大学総合研究機構火災科学研究センター 教授. 工博

***** 東京理科大学理学部数理情報科学科 教授 $\cdot$ 理博

Yamatoprotec Corp. \& Dept. of Architecture, Graduate School of Science and Technology, Tokyo University of Science, M. Sci.

Yamatoprotec Corp., M. Eng.

Assoc. Prof., Center for Fire Science and Technology, Research Institute for Science and Technology, Tokyo University of Science, Dr. Eng.

Prof., Center for Fire Science and Technology, Research Institute for Science and Technology, Tokyo University of Science, Dr. Eng.

Prof., Dept. of Mathematical Information Science, Faculty Science Division 1, Tokyo University of Science, Dr. Sci.
} 


\section{2. 本研究の概要}

本稿では、散水を伴わず燃焼のみを行う実験を「自由燃焼実験」、 燃焼物に散水を行う実験を「消火実験」、燃焼を伴わず散水のみを行 う実験を「散水実験」と定義する。

本研究では燃焼物を $0.9 \mathrm{~m}$ 角木材クリブとし、最初に、自由燃焼実 験時の重量減少法にて測定した発熱速度と放射熱流束の関係式を求 める。その時、天井とクリブ上面の距離による燃焼速度の影響を調 べる。次に、放射熱流束から逆算した重量減少量と、燃え残り重量 から算出した重量減少量との関係を求める。その結果、これらの量 には比例関係が見られる。この関係をスプリンクラーの水滴による 放射熱流束の減衰によるものと仮定し、Mie理論を適用してその減 衰を求めた結果、良い精度で一致している。

\section{3. 自由燃焼実験時の放射熱流束}

最初に自由燃焼実験の際の発熱速度と放射熱流束の関係を求めた。

\section{1. 自由燃焼実験概要}

自由燃焼実験では、天井高さが燃焼に影響を及ぼすかどうか示す

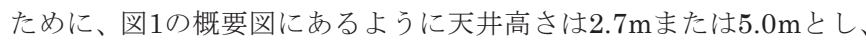
前者の場合にはクリブ高さ調節台を床上 $0 、 0.5$ 、および $1 \mathrm{~m} の$ 高さに 設定して実験を行った。

表1に示すように、クリブは6、9、および12段の 3 通りとし、使用 した測定器等は表 2 に示寸。実験中の放射計とロードセルの計測デ 一タは、横河電機製WE7000を用いて、サンプリング周期を $1 \mathrm{~Hz}$ と した。実験条件は表3に示す通りである。

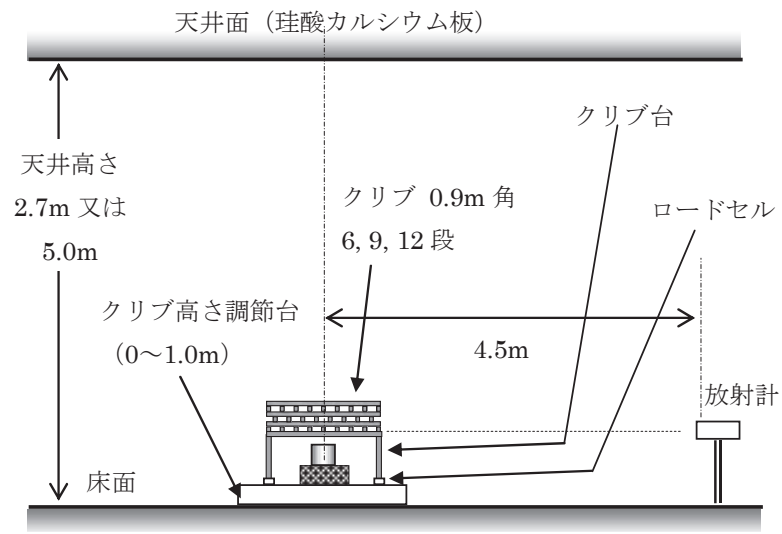

図1 自由燃焼実験の概要

表1 木材クリブ仕様

\begin{tabular}{|c|c|c|c|}
\hline 段 数 & 6段 & 9段 & 12段 \\
\hline 材 質 & \multicolumn{3}{|c|}{ "杉（サイズ30×40×900mm) } \\
\hline 含水率 & \multicolumn{3}{|c|}{$8 \sim 12 \%$} \\
\hline 本数、重量 & 58本 $($ 約 $24 \mathrm{~kg})$ & 86本 (約 $36 \mathrm{~kg}$ ) & 114本 (約 $47 \mathrm{~kg}$ ) \\
\hline 着火用火血. & \multicolumn{3}{|c|}{$\begin{array}{l}\varphi 120 \mathrm{~mm} \text { 中央に設置 ヘプタン } 100 \mathrm{ml} \\
\text { 火血上端〜クリブ下端が } 100 \mathrm{~mm} \text { とした }\end{array}$} \\
\hline
\end{tabular}

\section{表2 測定装置}

\begin{tabular}{|c|c|c|c|c|}
\hline 測定項目 & 測定器 & メーカー & 型番 & 測定レンジ等 \\
\hline \hline 放射受熱量 & 放射計 & 東京精工 & RE-III & $0 \sim 9 \mathrm{~kW} / \mathrm{m}^{2}$ \\
\hline \multirow{2}{*}{ 重 量 } & ロードセル & 共和電業 & LUB- $50 \mathrm{~KB}$ & $50 \mathrm{~kg} \times 4$ 台 \\
\cline { 2 - 5 } & 台はかり & 島津製作所 & EB- $32 \mathrm{KDVW}$ & $0 \sim 32 \mathrm{~kg}$ \\
\hline 木材含水率 & 木材水分計 & ケット & MT- $8 \mathrm{~S}$ & $4 \sim 30 \%$ \\
\hline
\end{tabular}

なお、 RE-III型放射計は、白金ブラックを塗布したサーモパイル を受熱素子としており、測定環境に対する温度補償機能を備えてい る。空フィルタには有効透過が広範 $(0.5 \sim 27 \mu \mathrm{m})$ な臭化タリウム と塩化タリウムの混合物を使用している。

表3 実験条件および火災成長係数 $\alpha$ と最大発熱速度

\begin{tabular}{|c|c|c|c|c|c|}
\hline $\begin{array}{l}\text { 実験 } \\
\text { 番号 }\end{array}$ & $\begin{array}{l}\text { 天井 } \\
\text { 高さ }\end{array}$ & 段 数 & 台高さ & $\begin{array}{c}\mathrm{a} \\
{\left[\mathrm{kW} / \mathrm{s}^{2}\right]}\end{array}$ & $\begin{array}{l}\text { 最大発熱 } \\
\text { 速度 }[\mathrm{kW}]\end{array}$ \\
\hline F1 & \multirow{7}{*}{$2.7 \mathrm{~m}$} & \multirow{8}{*}{6} & \multirow{3}{*}{$0.0 \mathrm{~m}$} & 0.0078 & 885.5 \\
\hline F2 & & & & 0.0059 & 811.9 \\
\hline F3 & & & & 0.0083 & 878.7 \\
\hline F4 & & & \multirow{2}{*}{$0.5 \mathrm{~m}$} & 0.0057 & 819.2 \\
\hline F5 & & & & 0.0039 & 762.6 \\
\hline F6 & & & \multirow{2}{*}{$1.0 \mathrm{~m}$} & 0.0090 & 870.3 \\
\hline F7 & & & & 0.0098 & 832.5 \\
\hline F8 & $5.0 \mathrm{~m}$ & & $0.0 \mathrm{~m}$ & 0.0098 & 894.1 \\
\hline F9 & \multirow{5}{*}{$2.7 \mathrm{~m}$} & \multirow{6}{*}{9} & $0.0 \mathrm{~m}$ & 0.0177 & 1299.9 \\
\hline F10 & & & \multirow{2}{*}{$0.5 \mathrm{~m}$} & 0.0153 & 1308.0 \\
\hline F11 & & & & 0.0135 & 1413.2 \\
\hline F12 & & & \multirow{2}{*}{$1.0 \mathrm{~m}$} & 0.0149 & 1433.8 \\
\hline F13 & & & & 0.0150 & 1387.3 \\
\hline F14 & $5.0 \mathrm{~m}$ & & $0.0 \mathrm{~m}$ & 0.0183 & 1411.7 \\
\hline F15 & \multirow{5}{*}{$2.7 \mathrm{~m}$} & \multirow{6}{*}{12} & \multirow{2}{*}{$0.0 \mathrm{~m}$} & 0.0186 & 1728.3 \\
\hline F16 & & & & 0.0225 & 1770.2 \\
\hline F17 & & & \multirow{2}{*}{$0.5 \mathrm{~m}$} & 0.0232 & 1786.3 \\
\hline F18 & & & & 0.0184 & 1731.8 \\
\hline F19 & & & $1.0 \mathrm{~m}$ & 0.0273 & 1854.2 \\
\hline F20 & $5.0 \mathrm{~m}$ & & $0.0 \mathrm{~m}$ & 0.0248 & 1859.8 \\
\hline
\end{tabular}

\section{2. 実験結果}

\section{2. 1. 火災成長係数 $\alpha$ と台高さの関係}

液体燃料では、天井高さが低くなると発熱速度の最大值が増加し、 それに至る時間も早くなることが指摘されている4)。本研究では固 体燃料であるため、これらと同様な傾向があるか、クリブ〜天井間 の距離と火災成長係数 $\alpha$ や最大発熱速度との関係を求めた。

図 2 に例示するように、火災成長期における発熱速度は、 $\dot{Q}(t)=\alpha\left(t-t_{0}\right)^{2}$ の形にフィッティングさせた。なお、 $\alpha$ の計算には最小 二乗法を用いた (付録 $\mathrm{A}$ 参照)。木材の単位重量当たりの発熱量は、 $17.76 \mathrm{~kJ} / \mathrm{g}$ を使用した5)。

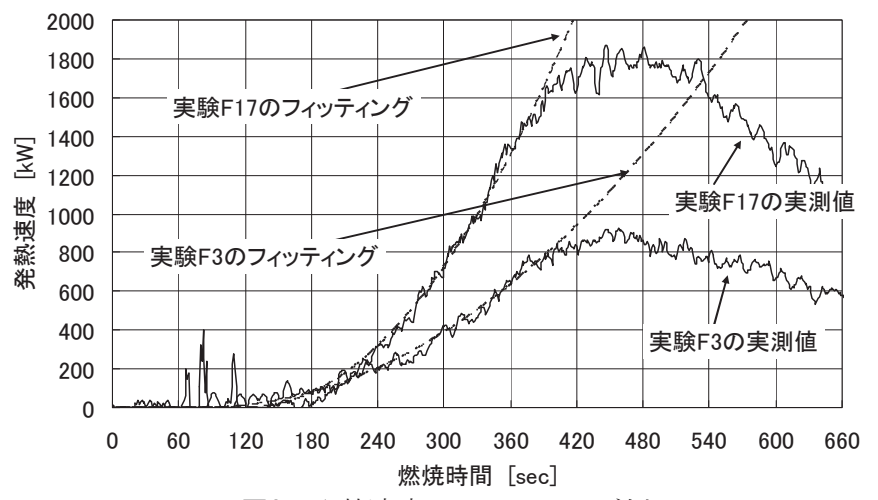

図2 発熱速度フィッティング例

各実験における $\alpha$ を表3に、段数と $\alpha$ の関係、および台高さと $\alpha$ の関係を図3および図4にそれぞれ示す。

図3からは、クリブ段数と $\alpha$ の間には、台高さすなわち天井との 
距離によらず強い相関が見られるものの、図4からは天井との距離 と $\alpha$ の間には相関が見られないことが確認できる。したがって、段 数に対しては強い依存性があるが、クリブと天井間の距離に対して 依存性は見られないことが分かった。

同様に、最大発熱速度についても、図 5 および図 6 に示寸通り、 段数に対し強い依存性を持つものの、クリブ台高さ、つまり天井と クリブ間の距離に対して依存性は確認できなかった。

以上の結果から、火災成長係数と最大発熱速度はクリブと天井間 の距離には依存せず、段数のみに依存することが分かった。したが って、以後では天井とクリブの間の距離は、火源に対して影響を与 えないとした。

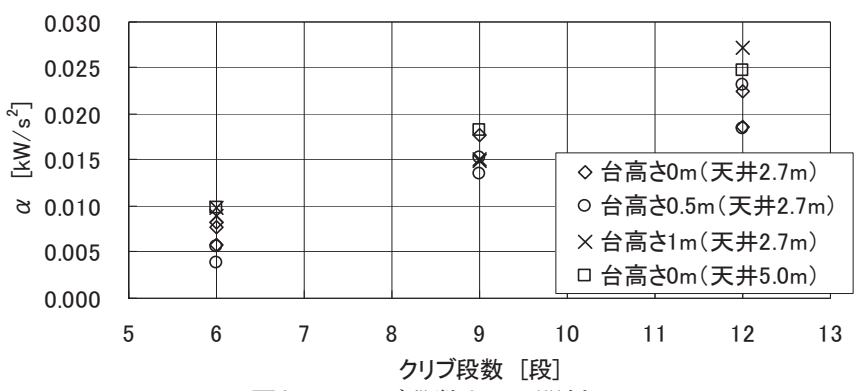

図3 クリブ段数とaの関係

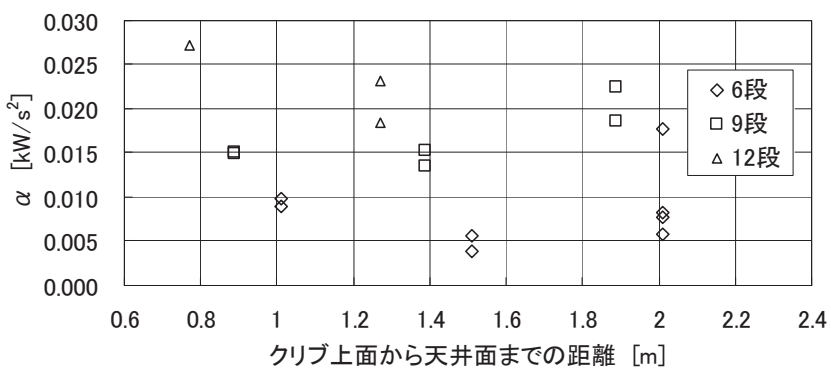

図4クリブ上面と天井面の距離と $\alpha$ の関係（天井高 $2.7 \mathrm{~m}$ ）

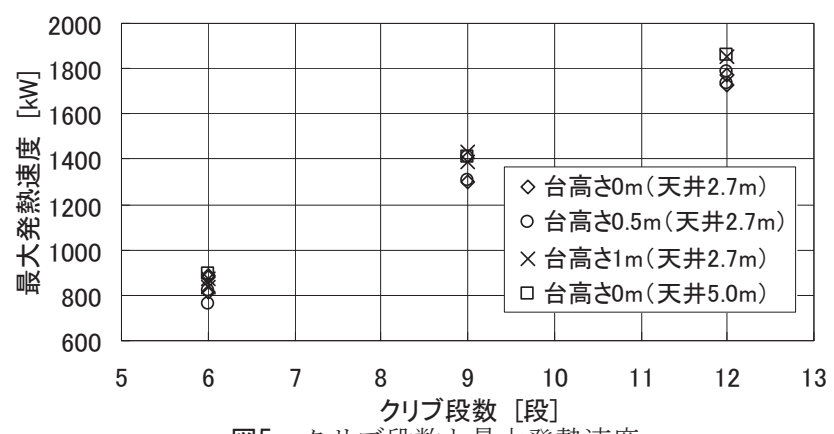

図5 クリブ段数と最大発熱速度

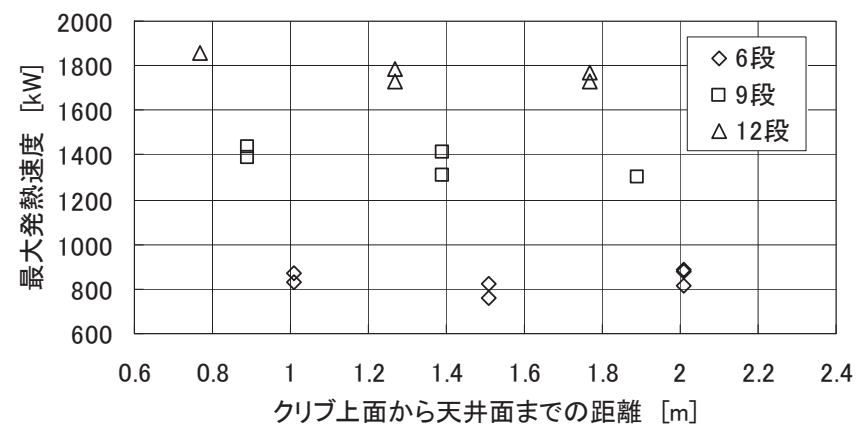

図6 クリブ上面と天井面の距離と最大発熱速度（天井高2.7m)

\section{2. 2. 発熱速度と放射熱流束の関係}

燃焼に伴う放射熱流束に関しては、発熱速度と累乗関係があると 報告されている6)。本研究の火災模型においても、放射熱流束は発 熱速度と一定の関係が存在していると仮定し、それぞれの段数に応 じて発熱速度 $\dot{Q}^{(\mathrm{kW})}$ と放射熱流束 $q^{\prime}\left(\mathrm{W} / \mathrm{m}^{2}\right)$ の関係を求めた。

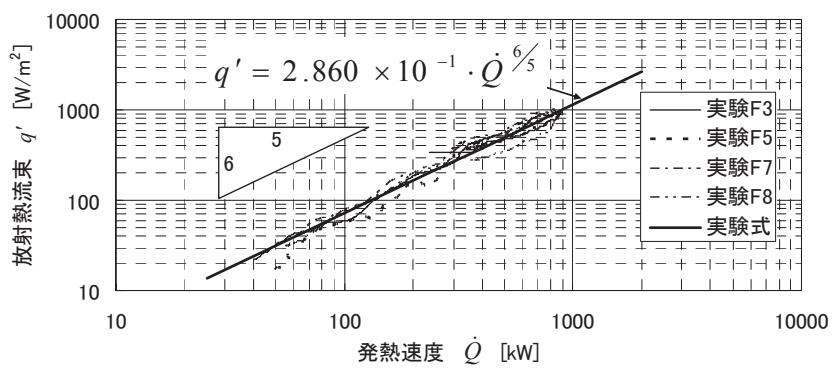

図7 6段クリブの発熱速度と放射熱流束の関係

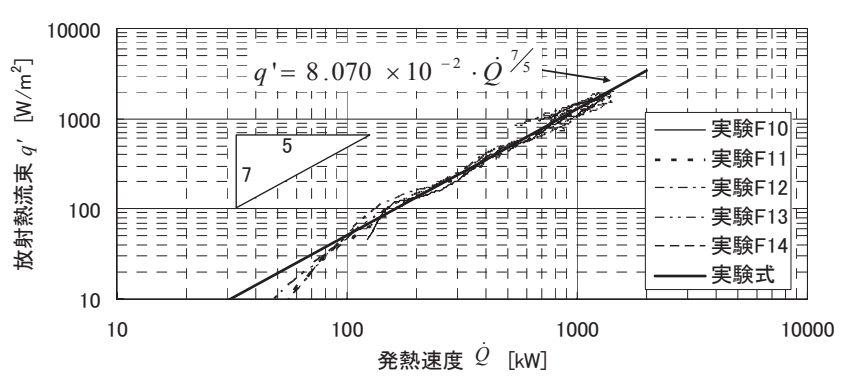

図8９段クリブの発熱速度と放射熱流束の関係

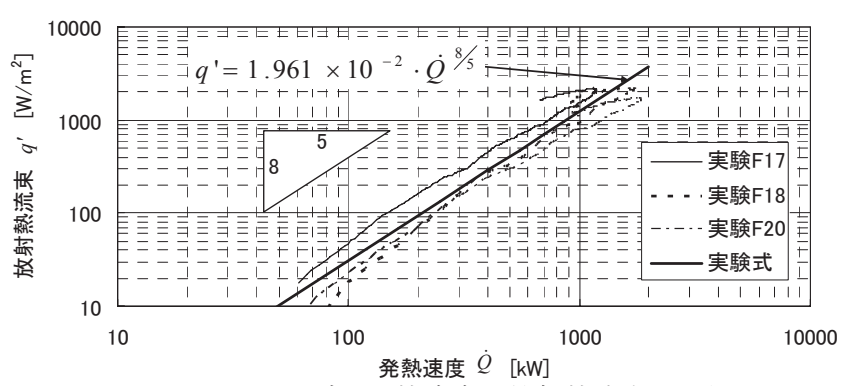

図9 12段クリブの発熱速度と放射熱流束の関係

実験から発熱速度と放射熱流束について累乗関係の結果を得た。 しかし、図9において見られるように、12段クリブにおいては多少 の誤差が見られるが、影響ないと考えた。そこで、既往の研究 ${ }^{6,7)}$ を踏襲し放射熱流束と発熱速度の間の実験式を、(2)〜 (4)式に示す。

$$
\begin{array}{ll}
\text { [ 6段] } & q^{\prime}=2.860 \times 10^{-1} \cdot \dot{Q}^{6 / 5} \\
{[\text { 9段 }]} & q^{\prime}=8.070 \times 10^{-2} \cdot \dot{Q}^{7 / 5} \\
\text { [12段 }] & q^{\prime}=1.961 \times 10^{-2} \cdot \dot{Q}^{8 / 5}
\end{array}
$$

段数の増加に伴い、次数は増加、係数は減少傾向となった。これ は、木材クリブの場合、発熱速度が低い燃焼初期はクリブ中心部で の燃焼が支配的であるためと考えられる。つまり、段数が増えるほ ど外縁部の未燃焼木材により、燃焼初期の放射が十分に外部に伝わ らず、発熱速度が低い段階の放射熱流束が低くなってしまうため、 傾きが大きくなってしまったことが原因であると推察される。

これらの実験式と、簡易式である(5)式8)の比較結果を図10に示す。 
ただし、 $\chi_{f}$ は発熱速度のうち放射成分の割合で本研究では $1 / 3$ とし た9)。Rは火源からの距離である。

$$
q^{\prime}=\chi_{f} \cdot \dot{Q} / 4 \pi R^{2} \times 1000
$$

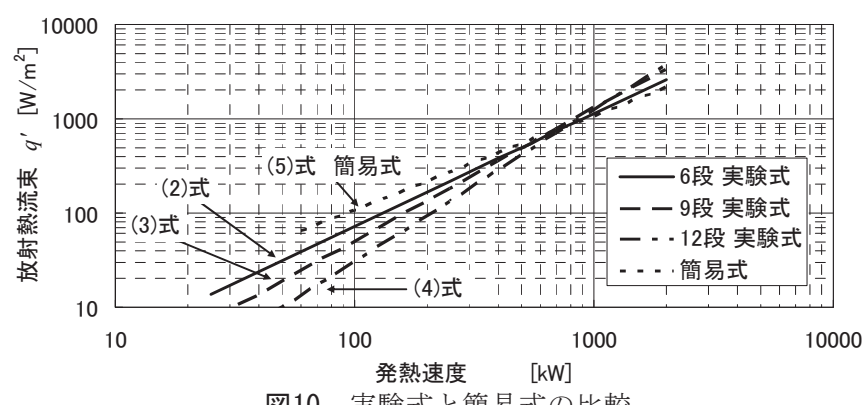

図10 実験式と簡易式の比較

(2)〜 (5)式は、概ね $2400 \mathrm{~kW}$ 以上熱速度が大きい領域では、大き な差は無かった。逆に、発熱速度が低い領域では、段数が多くなる に従い放射熱流速は減少しており、(5)式は低発熱速度領域で最も大 きな値となる6段の実験式よりも更に大きな值となった。このこと は、(5)式は火炎からの放射熱流束が指向性無く全立体角に一様に放 出されることを仮定8 しているので、前述したとおり段数が増える ほど外縁部の木材のため燃焼初期の放射が十分に外部に伝わらない と考えることができる。

\section{4．放水中の発熱速度と放射熱流束の関係}

自由燃焼実験での放射熱流束と発熱速度との関係式が、スプリン クラーの散水を行った実験にも適用できるか否かを検討した。

\section{1 . 消火実験概要}

消火実験には、自由燃焼実験時と同様に、6、9、および12段クリ ブを使用した。自由燃焼実験においては、クリブと天井間の距離は 燃焼に影響を与えないとしたため、天井高さは図11に示すように、 $2.7 \mathrm{~m}$ に固定した。図 12 に示寸ように、クリブ中心から $2.1 \mathrm{~m}$ の位置 にスプリンクラーヘッド（感度種別1種）を設置した。この位置で は木材クリブ全体が有効散水半径 $(2.6 \mathrm{~m})$ の範囲内である。

実験条件は表4の通りとし、放水開始のタイミングはそれぞれの クリブ段数における最大発熱速度の $1 / 3 、 2 / 3$ 、および 1 倍程度を目安 とし、6段のみ $1 / 2 を$ 追加した。

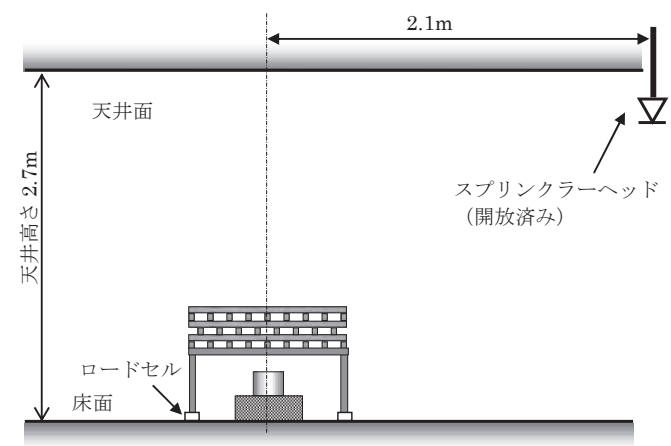

図11 消火実験概要（断面図）

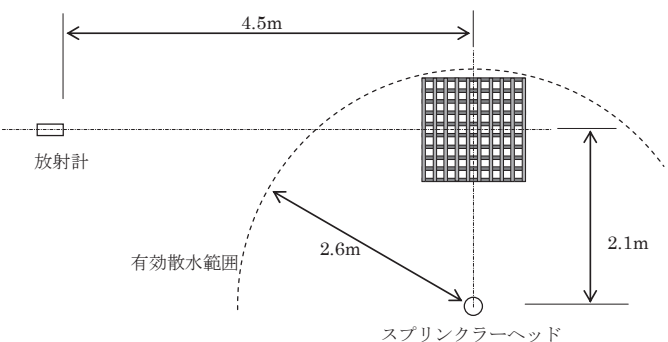

図12 消火実験概要（平面図）

表4 消火実験の実験条件と重量減少

\begin{tabular}{|c|c|c|c|}
\hline $\begin{array}{l}\text { 実験 } \\
\text { 番号 } \\
\end{array}$ & $\begin{array}{l}\begin{array}{l}\text { クリブ } \\
\text { 段数 }\end{array} \\
\end{array}$ & $\begin{array}{l}\text { 散水タイ } \\
\text { ミング* } \\
\end{array}$ & $\begin{array}{c}\text { 散水中の } \\
\text { 重量減少 }[\mathrm{kg}]\end{array}$ \\
\hline E1 & \multirow{4}{*}{6} & $1 / 3 \dot{Q} \max$ & 0.469 \\
\hline E2 & & $1 / 2 \dot{Q} \max$ & 1.223 \\
\hline E3 & & $2 / 3 \dot{Q m a x}$ & 3.058 \\
\hline $\mathrm{E} 4$ & & $Q \max$ & 5.079 \\
\hline E5 & \multirow{3}{*}{9} & $1 / 3 \dot{Q} \max$ & 21.011 \\
\hline E6 & & $2 / 3 \dot{Q} \max$ & 21.513 \\
\hline E7 & & $Q \max$ & 16.180 \\
\hline E8 & \multirow{3}{*}{12} & 1/3 $\dot{Q} \max$ & 33.127 \\
\hline E9 & & $2 / 3 \dot{Q} \max$ & 33.628 \\
\hline E10 & & $\dot{Q \max }$ & 21.997 \\
\hline
\end{tabular}

*Qmaxはそれぞれの段数におけるおよその発熱速度最大值を示す。

\section{2. 散水中の重量減少の測定方法}

木材クリブの消火実験では、散水中にクリブ自身が水を吸収する ため、ロードセルでの重量減少を測定することができない。しかし、 散水開始前までの重量減少はロードセルにより得られ、消火実験に よる重量減少は実験前の木材の総重量と実験終了後の燃え残り重量 との差によって得られる。

以上をまとめると、散水中の重量減少は次のように考えられる。

(散水中の重量減少)

$=$ （消火実験による重量減少）-（散水開始前までの重量減少）

なお、実験終了直後の燃え残りは多量の水を含んでいるため、6 ヶ月以上屋内にて自然乾燥させた上で、含水率を実験前の含水率と 同程度に調整して測定した。測定によって得られた散水中の重量減 少を表4に示す。

\section{3. 実験結果}

3.2.2で得られた発熱速度と放射熱流束の関係式(2)〜 (4)を用い、 散水中の放射測定值から散水中の発熱速度が得られる。この発熱速 度から散水中の重量減少 $\Delta m_{\text {rad }}$ 算出寸る。図13に実際の散水中の重 量減少 $\Delta m_{a c t}$ との比較を示す。

両者はの関係は、段数に依存せず、全体として直線性もありばら つきも小さい。回帰直線からは、 $\Delta m_{\text {rad }}$ の方がおおむ称 $18 \%$ 程度低い 值となった。これは放射吸収量に換算して $13.6 \%$ 分の吸収に相当す る (付録B参照)。段数に依存しないことから、本研究における放射 吸収量は発熱速度に依存しないと推測され、放水中の放射熱流束に 対してこの低下分を補正し、改めて発熱速度を計算すれば、放水中 の発熱速度を得ることができると考えられる。 


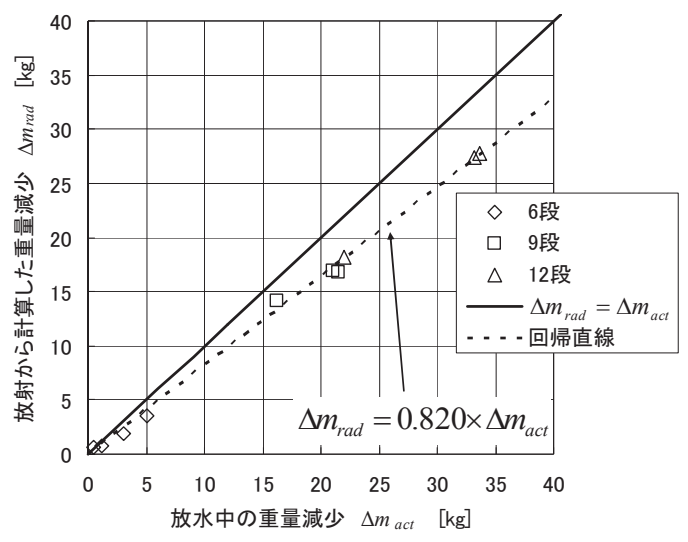

図13 放射熱流束から計算した放水中の重量変化

上記の手順によって計算した発熱速度を、重量減少法によって計 算した自由燃焼実験時（実験F3、F9、F16）の発熱速度と共に図14 〜図16に示す。

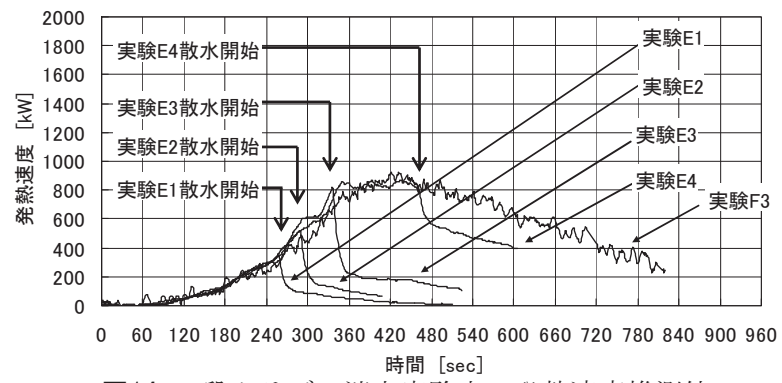

図14 6段クリブ 消火実験中の発熱速度推測值

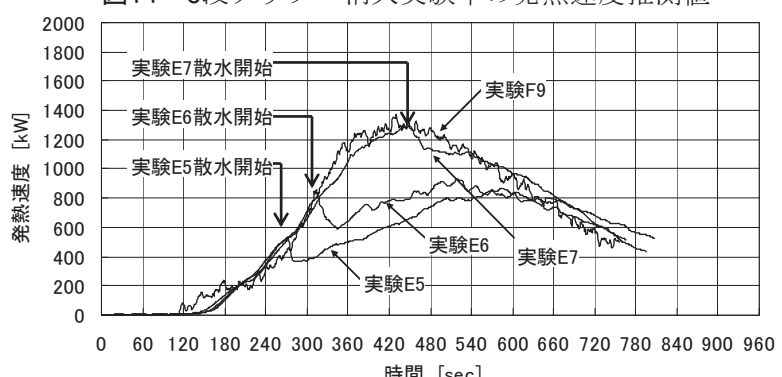

図15９段クリブ＼cjkstart消火実験中の発熱速度推測值

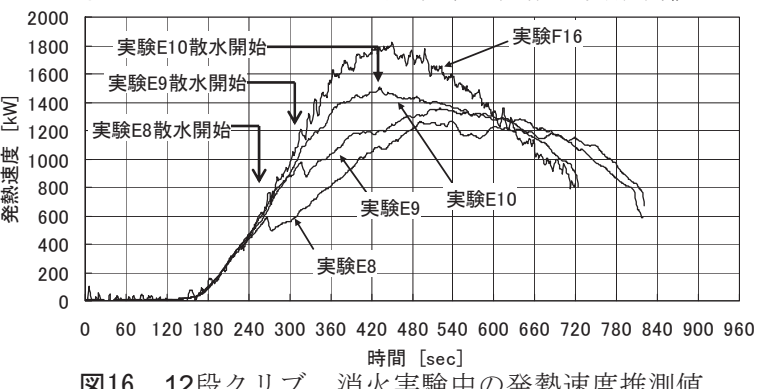

図16 12段クリブ 消火実験中の発熱速度推測值

以上の方法は、散水中の放射減衰率が得られている（本研究では 重量減少の比較による）場合に使用可能な方法であるが、一般的に は前もって放射減衰率を得ることは困難である。しかし、散水状況 から放射減衰率を見積もることができれば、散水分布測定結果と実 験時の放射熱流束の測定値から、散水中の発熱速度を計算すること が可能となる。散水中の放射熱流束の減衰の理由の一つとして、ス プリンクラーの水滴による放射吸収が考えられる。水滴による放射 吸収に関する検討を次で行う。

\section{5. 水滴による放射吸収の見積もり}

前述より、スプリンクラー (以下、SP) による木材クリブの消火 実験時に放射熱流束が13.6\%減衰することが分かった。これは、SP の水滴によって放射熱流束が減衰しているものと考えられる。本章 ではMie理論を用いて、水滴による放射熱流束の吸収に関寸る検討 を行う。

\section{1. SP散水による空間中の水滴密度}

水滴による放射熱流束の吸収を考える場合、放射計と火炎との間 の水滴密度が重要となる。本研究では、水滴半径を $400 \mu \mathrm{m}$ 、水滴 粒子速度 $v$ を $4 \mathrm{~m} / \mathrm{s}$ と仮定し 10$)$ 、散布水量の測定值を元に水滴密度を 計算する。なお、SPヘッドから散布される水滴は、緩やかな放物線 状の軌跡を描いて飛散するが、本研究では簡単のために、SPへッド から直線状に飛散するものとモデル化する。

クリブ上面の中心を原点とし、 $\mathrm{SP}$ ヘッドまでの水平距離を $Y$ 、高 さをZとする（図17）。火源から放射計に向かう方向を $x$ 軸、位置 $x$ に おける散布水量を $D(x)$ とする（図18）。

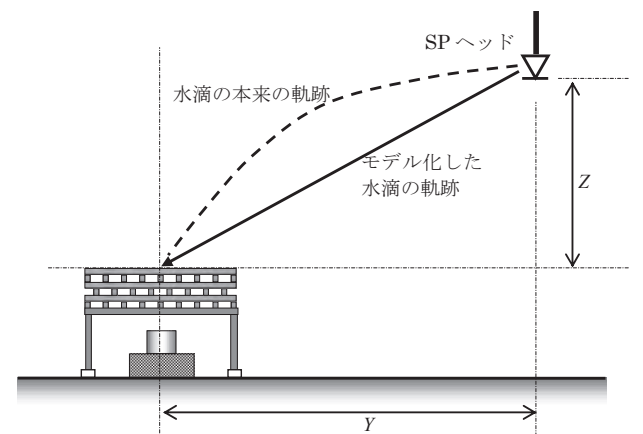

図17 モデル化した水滴の軌跡（断面図）

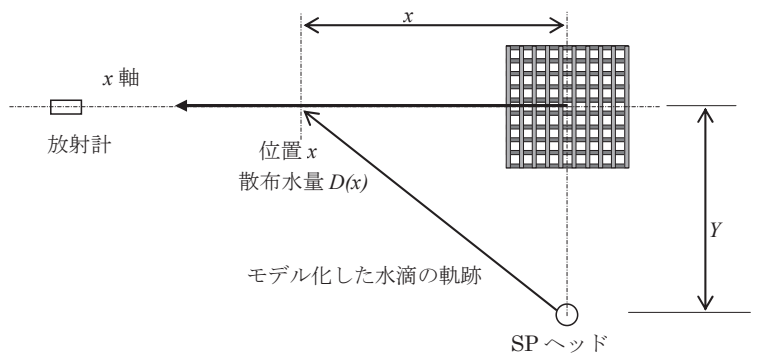

図18 モデル化した水滴の軌跡（平面図）

このとき、水滴粒子の速度をv、半径を $a$ とすると、位置 $x$ における 単位体積あたりの密度 $n(x)$ は、次式から得られる。

$$
n(x)=\frac{3 D(x) \sqrt{x^{2}+Y^{2}+Z^{2}}}{4 \pi a^{3} v Z}
$$

実際に散布水量 $D(x)$ を測定した結果を図19に、(6)式を用いて計算 した水滴密度を図20にそれぞれ示す。

散布水量、水滴密度ともに段数によってそれほどの变化は無かっ た。以後の利便性を考え、水滴密度に関しては、段数によらず図 20 に示す平均值で代表するものとする。 


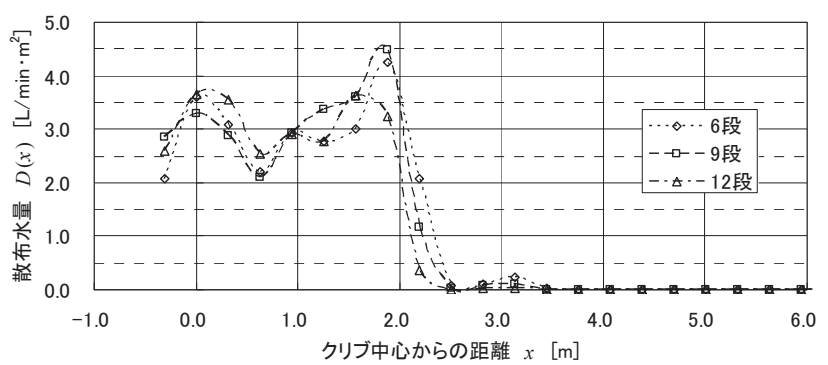

図19 x軸（クリブ〜放射計方向）の散布水量

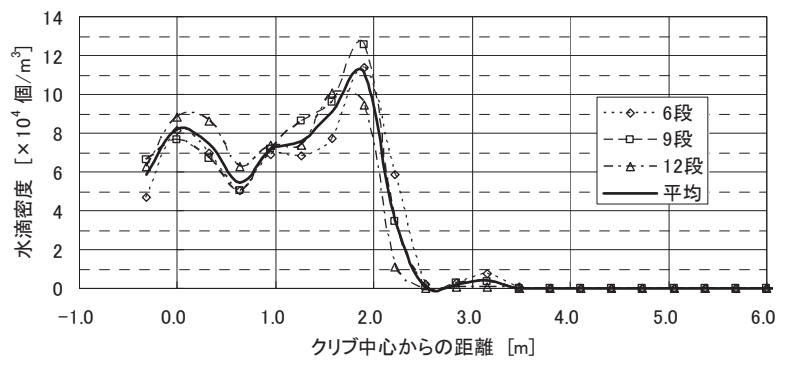

図20x軸（クリブ〜放射計方向）上の水滴密度

\section{2. 単一水滴による散乱と吸収の計算}

まず、単一の水滴による放射の散乱・吸収について検討する。均 一媒質内における均一な球による電磁波の散乱・吸収については、 MieによってMaxwell方程式を解析的に解いた研究が知られており、 一般的にMie散乱と呼ばれている11)。水滴による散乱断面積と吸収 断面積およびそれらの和である消散断面積をそれぞれ水滴の断面積 で割った散乱効率、吸収効率、および消散効率 (それぞれ $Q_{s c a} 、 Q_{a b s}$ 、 および $Q_{e x t}$ とおく) は、(7)〜(9)式で求められる12)。

$$
\begin{aligned}
& Q_{s c a}=\frac{2}{x^{2}} \sum_{n=1}^{\infty}(2 n+1) \cdot\left(a_{n} a_{n}^{*}+b_{n} b_{n}^{*}\right) \\
& Q_{e x t}=\frac{2}{x^{2}} \sum_{n=1}^{\infty}(2 n+1) \cdot \operatorname{Re}\left(a_{n}+b_{n}\right) \\
& Q_{e x t}=Q_{s c a}+Q_{a b s}
\end{aligned}
$$

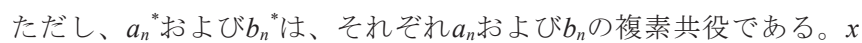
はサイズパラメーターであり、波長を入、水滴半径を $a$ とおくと、 $x=2 \pi a / \lambda$ ゲちられる。 $a_{n}$ と $b_{n}$ の值は、次の $(10) \sim(11)$ 式で得られる。

$$
\begin{aligned}
& a_{n}=\frac{m \psi_{n}(m x) \psi_{n}^{\prime}(x)-\psi_{n}(x) \psi_{n}^{\prime}(m x)}{m \psi_{n}(m x) \xi_{n}^{\prime}(x)-\xi_{n}(x) \psi_{n}^{\prime}(m x)} \\
& b_{n}=\frac{\psi_{n}(m x) \psi_{n}^{\prime}(x)-m \psi_{n}(x) \psi_{n}^{\prime}(m x)}{\psi_{n}(m x) \xi_{n}^{\prime}(x)-m \xi_{n}(x) \psi_{n}^{\prime}(m x)}
\end{aligned}
$$

$\psi_{n}(z)$ と $\xi_{n}(z)$ はリカッチーベッセル関数であり、球ベッセル関数 $j_{n}(z)$ と第 1 種球ハンケル関数 $h_{n}^{(1)}(z)$ を用いて次のように表される。

$$
\psi_{n}(z)=z \cdot j_{n}(z) \quad 、 \xi_{n}(z)=z \cdot h_{n}^{(1)}(z)
$$

$m$ は水の屈折率であり、吸収を考慮する場合は複素数であり $(m=n+i k)$ 、実部・虚部共に波長によって值が異なる。本研究では Haleらによって示された值を使用した ${ }^{13)}$ 。水滴半径を $400 \mu \mathrm{m}$ と仮 定 ${ }^{10)}$ し、計算によって得られた散乱効率、吸収効率、および消散効 率の值を図 21 に示す。

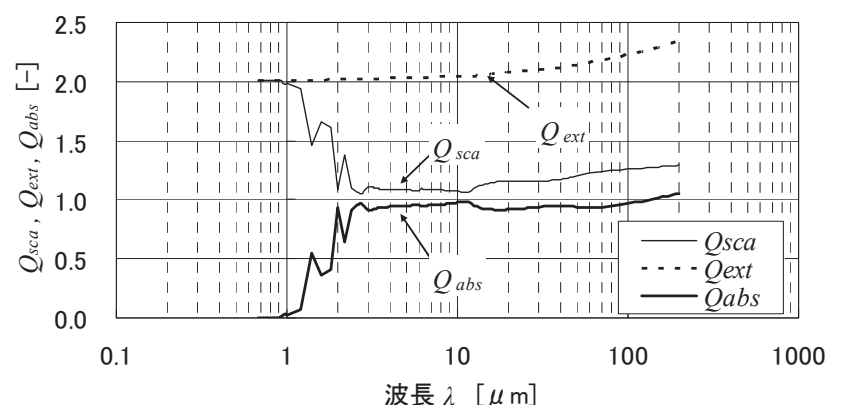

図21 散乱・消散・吸収効率の波長依存性

\section{3. 水滴群による散乱と吸収の計算}

前記の検討は、単一の水滴による散乱・消散・吸収に関するもの であった。しかし、実験において観測される放射減衰は、付録Cに 示すようなスペクトル分布を持つ放射が、多数の水滴群によって散

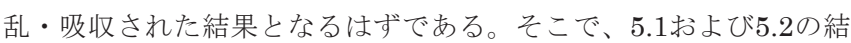
果を利用して水滴群に適用寸ることを試みる。

本研究で仮定した水滴半径は $400 \mu \mathrm{m}$ であり、図20に示した水滴 密度の最大值（ $1.11 \times 10^{5}$ 個 $/ \mathrm{m}^{3} ）$ においても高々 $2.7 \times 10^{-8} \%$ の体積 を占めるに過ぎない。水滴粒子間の距離が波長に比べて十分大きい 場合は、それぞれの水滴によって散乱された光はコヒーレントでは ない14)。したがって、以下では散乱光同士の干渉は無視できると考 える。空間中の黒体放射が無視できる場合、散乱を考慮した放射の 伝達方程式は、散乱角を図22、方位角を図23で定義すると、(13)式 になる15),16)。

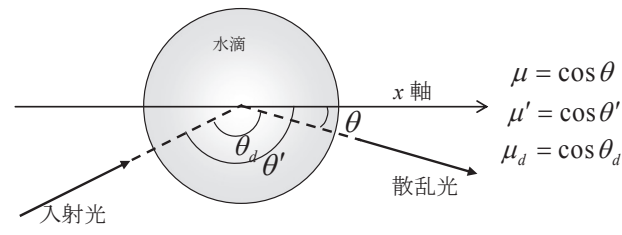

図22＼cjkstart散乱角の定義

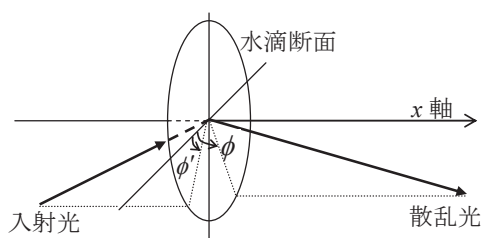

図23 方位角の定義

$$
\begin{aligned}
& \mu \frac{d I_{\lambda}(x, \mu, \phi)}{d x}+a_{\lambda, e x t} I_{\lambda}(x, \mu, \phi) \\
& =\frac{a_{\lambda, s c a}}{4 \pi} \int_{\phi^{\prime}=0}^{2 \pi} \int_{\mu^{\prime}=-1}^{1} P\left(\mu, \phi, \mu^{\prime}, \phi^{\prime}\right) \cdot I_{\lambda}\left(x, \mu^{\prime}, \phi^{\prime}\right) d \mu^{\prime} d \phi^{\prime}
\end{aligned}
$$

ただし、各変数は次の通りである。

$\mu 、 \mu^{\prime}$ 入射光および散乱光がx軸となす角度の余弦

$\phi 、 \phi^{\prime}$ 入射光および散乱光の方位角

$I_{\lambda} \quad$ 波長 $\lambda$ の放射強度

$n(x) \quad$ 位置 $x$ における水滴密度

a 水滴半径

$a_{\lambda, e x t} \quad$ 波長 $\lambda$ の消散係数。 $a_{\lambda, e x t}=n(x) \cdot \pi a^{2} \cdot Q_{\text {ext }}$

$a_{\lambda, s c a} \quad$ 波長 $\lambda$ の散乱係数。 $a_{\lambda, s c a}=n(x) \cdot \pi a^{2} \cdot Q_{s c a}$

$P\left(\mu, \phi, \mu^{\prime}, \phi^{\prime}\right) \quad(\mu, \phi)$ の入射方向から $\left(\mu^{\prime}, \phi^{\prime}\right)$ の方向に散乱する 場合の位相関数 
(13)式に 2 流束モデルを適用し、 $0 \leqq \mu \leqq 1$ の成分を持つ $I_{\lambda}$ を $I^{+} 、-1 \leqq$ $\mu \leqq 0$ の成分を持つ $I_{\lambda}$ を $I^{-}$とする。方位角方向に対しては対称である ことを利用して $\phi^{\prime}$ に関する積分を実行し、得られた式に $\mu$ に関する 積分を作用させると(14)および(15)式が得られる16)。

$$
\begin{gathered}
\frac{1}{2} \frac{d I_{\lambda}^{+}}{d x}=-\left(a_{\lambda, e x t}-a_{\lambda, s c a}+a_{\lambda, s c a} \cdot B\right) I_{\lambda}^{+}+a_{\lambda, s c a} \cdot B \cdot I_{\lambda}^{-} \\
-\frac{1}{2} \frac{d I_{\lambda}^{-}}{d x}=-\left(a_{\lambda, e x t}-a_{\lambda, s c a}+a_{\lambda, s c a} \cdot B\right) I_{\lambda}^{-}+a_{\lambda, s c a} \cdot B \cdot I_{\lambda}^{+}
\end{gathered}
$$

ここでBは、 $\bar{P}_{0}$ をMie散乱の計算にて得られる位相関数として、 次の式で定義される量である16)。具体的な值は付録 $\mathrm{D}$ に示した。

$$
B=\int_{\mu=0}^{1} \int_{\mu^{\prime}=-1}^{0} \int_{\mu_{d}=\mu_{d, 0}}^{\mu_{d, \pi}} \frac{\frac{1}{2 \pi} \bar{P}_{0}\left(\operatorname{Cos}^{-1} \mu_{d}\right) \cdot d \mu_{d} d \mu^{\prime} d \mu}{\sqrt{\left(1-\mu^{2}\right)\left(1-\mu^{\prime 2}\right)-\left(\mu_{d}-\mu \mu^{\prime}\right)^{2}}}
$$

ただし、 $\mu_{d, 0} \equiv \mu \mu^{\prime}+\sqrt{1-\mu^{2}} \sqrt{1-\mu^{\prime 2}} 、 \mu_{d, \pi} \equiv \mu \mu^{\prime}-\sqrt{1-\mu^{2}} \sqrt{1-\mu^{\prime 2}}$ である。

付録Eに示したとおり、本研究のようなサイズパラメーターの領 域では前方散乱が非常に鋭いピークを持っており、その場合 $B$ の值

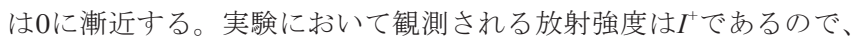
(14)式に $B=0$ を適用すると、

$$
\frac{1}{2} \frac{d I_{\lambda}^{+}}{d x}=-\left(a_{\lambda, \text { ext }}-a_{\lambda, s c a}\right) I_{\lambda}^{+}
$$

を得る。(8)式より、 $a_{\lambda, \text { ext }}=a_{\lambda, s c a}+a_{\lambda, a b s}$ であるから

$$
\frac{1}{2} \frac{d I_{\lambda}^{+}}{d x}=-a_{\lambda, a b s} I_{\lambda}^{+}=n(x) \cdot \pi a^{2} \cdot Q_{a b s} \cdot I_{\lambda}^{+}
$$

となる。したがって、(17)式に5.1で得られた水滴密度 $n$ と、 5.2 で得 られた吸収効率 $Q_{a b s}$ を代入して計算を行うと波長ごとの $x$ 方向に対 する放射強度 $\left(I_{\lambda}^{+}(x)\right)$ が計算可能となる。この計算結果と燃焼時の スペクトル分布の内積によって、観測される放射の減衰分が(18)式 で計算できる。

$$
I^{+}(x)=\int \bar{e}(\lambda) \times I_{\lambda}^{+}(x) d \lambda
$$

$$
\text { （ただし、 } \bar{e}(\lambda) \text { は規格化されたスペクトル分布とする。） }
$$

本研究では、 $x$ 方向に対する微分方程式の計算方法にRunge-Kutta 法を適用し、中間点における水滴密度は、 5.1 の測定值に対して3次 のスプライン計算17)を行って得た值を用いる。その結果、図 24 に示 すように、 $12.8 \%$ の減衰が水滴による吸収によって説明できること

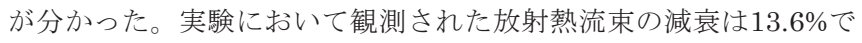
あり、非常に良く一致することから、本研究における実験で測定し た放射減衰は、水滴の吸収による減衰であると言える。

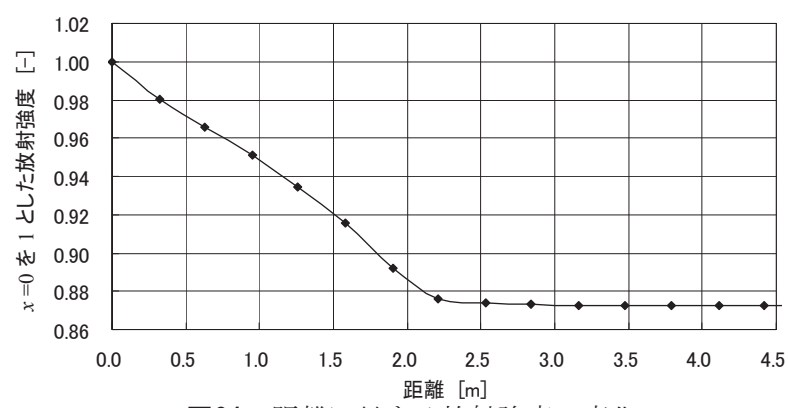

図24距離に対する放射強度の変化

\section{6. まとめ}

木材クリブに対してSPを散水した場合の発熱速度測定方法に関 して、燃焼後の乾燥重量の変化を基準として評価を行った。その結 果、本研究の条件においては、次のことが分かった。

(1) 本研究における条件では、クリブの燃焼と天井との距離に相 関は無く、段数にのみ依存する。

（2）発熱速度と放射熱流束との間に累乗関数形式の実験式が得ら れた。

（3）SP散水中の発熱速度について、放射熱流束から発熱速度を推 測した場合、実際の重量減少と比較し、約18\%減衰した值が得 られた。これは放射減衰分に換算すると、13.6\%に相当する。

（4）水滴による放射の吸収分を、Mie理論を用いて計算したところ、 本実験の散水分布条件では12.8\%が減衰することが分かり、散 水中の放射減衰分をよく説明できた。

したがって本論文においては、散水中の放射熱流束を測定し、散 水分布から得られた空間中の水滴密度を元に減衰分を補正すれば、 散水中の発熱速度を得ることが可能と考えた。

本研究において散水分布条件（=空間中の水滴密度条件）は1通 りであったが、他の散水分布条件でも同様な手法を適用できる可能 性がある。ただしクリブサイズも含め、燃焼物が異なる場合につい ては、改めて発熱速度と放射熱流束の関係を確認する必要がある。

今後の課題としては、他の水滴密度の分布条件においても、同様 にMie理論を用いて放射減衰量を求めることができるか実験が必要 である。その後、それらの散水条件での消火実験より得られる放射 減衰量を用い、同様な評価が可能か、検証が必要であろう。また、 本研究では水滴の吸収のみで放射吸収分がほぼ説明できたが，煙・ す寸等の影響を考慮すべき可燃物についても今後の課題である。

\section{謝辞}

本研究の一部は、平成17年度、18年度 文部科学省 科学研究費補 助金「火災成長期における天井流の火炎長の理論的研究と実験的 検証」により行われたものである。

\section{参考文献}

1）たとえば、山下誠治，塩谷暢生 : 我が国のスプリンクラーの消火効果に ついて, 火災, Vol.44, No.5, P.35, 1994

2) Evans, D.D. : Sprinkler Fire Suppression Algorithm for HAZARD, NISTIR 5254, National Institute of Standards and Technology, Gaithersburg, MD, 1993

3）総務省消防庁予防課：防火対象物の総合防火安全評価基準のあり方検討 会報告書 (平成 15 年度), 2004

4）土橋常登他: 建物空間における初期火災拡大性状の予測, GBRC, Vol.30, 122 号, P.37, 2005

5) Huggett, C. : Estimation of Rate of Heat Release by Means of Oxygen Consumption Measurements, Fire and Materials, Vol.4, No.2, P.61, 1980

6）長谷見雄二，徳永太造：乱流拡散火炎の巨視的性状のモデル化，日本火 災学会論文集, Vol.50, No.1, pp.9〜17, 1983

7）岡泰資他：トンネル火災時の輻射環境の推定法，地下空間シンポジウム 論文・報告集，第 11 巻，pp.61〜 70，2005

8）田中哮義 : 改訂版 建築火災安全工学入門, 日本建築センター, 2002

9）新谷祐介他：熱のフィードバック効果を考慮した延焼拡大モデル，日本 建築学会環境系論文集，Vol.74，No.641，pp.759～766, 2009.7

10）浅見高志：平成 6 年度日本火災学会研究発表会概要集，P.56, 1994 
11）柴田清孝: 光の気象学, 朝倉書店, 1999

12) Bohren, C.F. and Huffman, D.R. : Absorption and Scattering of Light by Small Particles, Wiley-VCH, 1998

13) Hale, G.H. and Querry, M.R. : Optical Constants of Water in the 200-nm to 200- $\mu \mathrm{m}$ Wavelength Region, Applied Optics, Vol.12, No.3 555 p., 1973

14) Born, M. and Wolf, E. 著 草川徹訳 : 光学の原理III, 東海大学出版会, 2006

15) Ozisik, M. : Radiative Transfer and interactions with conduction and convection, Wiley, 1973

16) Yang, W., et al. : The interaction of thermal radiation and water mist in fire suppression, Fire Safety Journal, Vol.39, Issue 1, pp.41 66, 2004

17）鈴木誠道、他：現代数值計算法，オーム社， 1994

\section{付録A}

実験によって得られた発熱速度 $\dot{Q}(t)$ と時間 $t$ から、 $\dot{Q}(t)=\alpha\left(t-t_{0}\right)^{2}$ の式で最 小二乗法を用いて定数 $\alpha 、 t_{0}$ を求める。

時刻 $t=\left\{t_{i} \mid i=1,2,3, \cdots, n\right\} \quad$ に沿った時系列実験データが $\dot{Q}(t)=\left\{\dot{Q}_{i} \mid i=1,2,3, \cdots, n\right\}$ で示されており、 $\dot{Q}(t)=\alpha\left(t-t_{0}\right)^{2}$ の形でフィッティングできるとする。実 験による $\dot{Q}_{i}$ の残差を $\delta_{i}$ とすると、

$$
\dot{Q}_{i}=\alpha\left(t_{i}-t_{0}\right)^{2}+\delta_{i}
$$

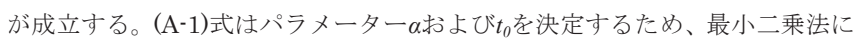
より

$$
\Delta \equiv \sum_{i=1}^{n} \delta_{i}^{2}=\sum_{i=1}^{n}\left[\dot{Q}_{i}-\alpha\left(t_{i}-t_{0}\right)^{2}\right]^{2}
$$

とし、次の 2 式を満たすことが条件である。

$$
\frac{\partial \Delta}{\partial \alpha}=0 \quad, \quad \frac{\partial \Delta}{\partial t_{0}}=0
$$

(A-3)式を $\alpha$ にいて解くと、次の 2 式が得られる。

$$
\begin{aligned}
& \alpha=\sum_{i=1}^{n} \dot{Q}_{i}\left(t_{i}-t_{0}\right)^{2} / \sum_{i=1}^{n}\left(t_{i}-t_{0}\right)^{4} \\
& \alpha=\sum_{i=1}^{n} \dot{Q}_{i}\left(t_{i}-t_{0}\right) / \sum_{i=1}^{n}\left(t_{i}-t_{0}\right)^{3}
\end{aligned}
$$

$(\mathrm{A}-4)$ 式から $\alpha$ を消去し $t_{0}$ を求め、得られた $t_{0}$ を $(\mathrm{A}-4)$ 式に代入することにより、 $\alpha か ゙$ 計算される。

\section{付録B}

消火実験において得られた散水中の重量減少から放射減衰分を逆算すると きは、次の関係を用いて計算した。

本研究において、自由燃焼実験時の放射 $q$ 'と発熱速度 $\dot{Q}$ の関係は次のように モデル化した（ $\alpha$ と $\beta$ はクリブ段数ごとに異なる定数）。

$$
q^{\prime}=\alpha \cdot \dot{Q}^{\beta}
$$

消火実験中の放射と発熱速度を $q^{\prime}{ }_{w}$ と $\dot{Q}_{w}$ とし、消火実験時の放射減衰率を $\gamma$ とおくと、(B-1)式は次のように書き直せる。

$$
q_{w}^{\prime}=(1-\gamma) \cdot \alpha \cdot \dot{Q}_{w}^{\beta}
$$

散水中の重量減少 $\Delta m_{a c t}$ は発熱速度の積分值 (=総発熱量) に比例するから、 比例係数を $1 / c$ ( $c$ =重量あたりの発熱量) として

$$
\Delta m_{a c t}=\frac{1}{c} \int \dot{Q}_{w} d t=\left(\frac{1}{1-\gamma}\right)^{\frac{1}{\beta}} \cdot \frac{1}{c} \int\left(\frac{q_{w}^{\prime}}{\alpha}\right)^{\frac{1}{\beta}} d t
$$
る $\Delta m_{\text {rad }}$ 、(B-1)式を用いたものであるから、

$$
\Delta m_{\text {rad }}=\frac{1}{c} \int\left(\frac{q_{w}^{\prime}}{\alpha}\right)^{\frac{1}{\beta}} d t
$$

である。(B-3)式と(B-4)式を各辺割り算して次式を得る。

$$
\Delta m_{\text {rad }} / \Delta m_{\text {act }}=(1-\gamma)^{\frac{1}{\beta}}
$$

本実験においては(B-5)式の右辺が0.820であり、防クリブ段数によって異 なる。計算の結果、 $\gamma$ は段クリブで $15.2 \%$ 、段クリブで $13.2 \%$ 、12段で $12.4 \%$ となり、平均は $13.6 \%$ となった。

\section{付録 C}

木材クリブの燃焼の際の放射スペクトルに関しては、下記の実験及び解析 を行った結果を用いた。

\section{（1）実験装置}

燃焼物としては6段クリブを用いた。仕様は本文中の表1と同じである。放 射スペクトルを測定するための分光分析器はCI SYSTEMS社製SR5000を使 用した。分光分析器の焦点は、燃焼初期から末期まで火炎を確認できるよう、 クリブ上面から $0.2 \mathrm{~m}$ の高さに設定した。

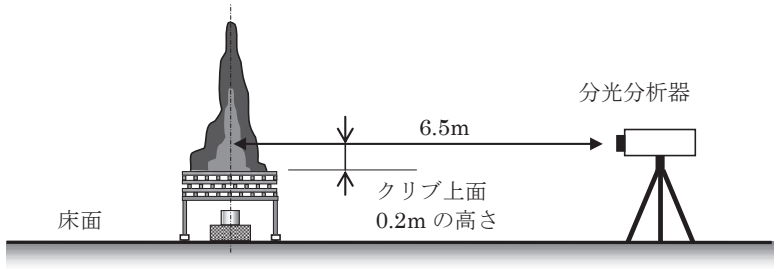

図C-1 実験装置

（2）スペクトル測定結果とその解析

クリブ燃焼は発熱速度が時間によって変化するため、放射強度も時間によ って変化する。実験によって測定されたスペクトルを、図C-2に示す。

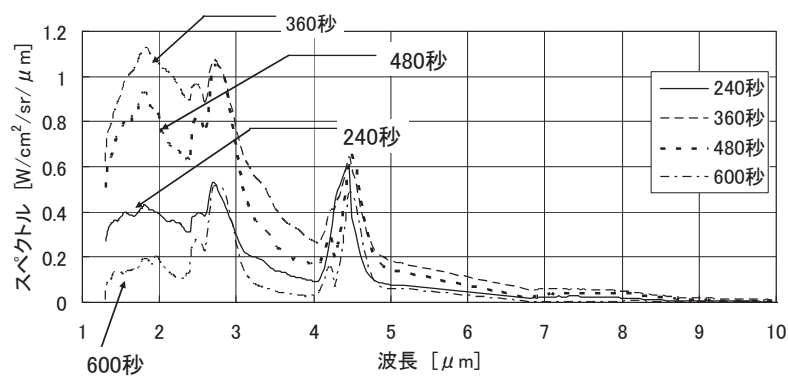

図C-2 スペクトルの時間変化

このスペクトルを、扱いやすいよう(C-1)式に示すように、観測波長全域の 積分值を用いて規格化し、燃焼中の時間平均をとった。

$$
\begin{aligned}
& e(\lambda, t)=E(\lambda, t) / \int E\left(\lambda^{\prime}, t\right) d \lambda^{\prime} \\
& \bar{e}(\lambda)=\sum_{i=1}^{n} e\left(\lambda, t_{i}\right) / n
\end{aligned}
$$

ここでれを波長とし、 $t$ を時間とすると、 $E(\lambda, t)$ は観測されたスペクトル、 $\bar{e}(\lambda)$ は規格化スペクトルの時間平均である（図C-3）。 


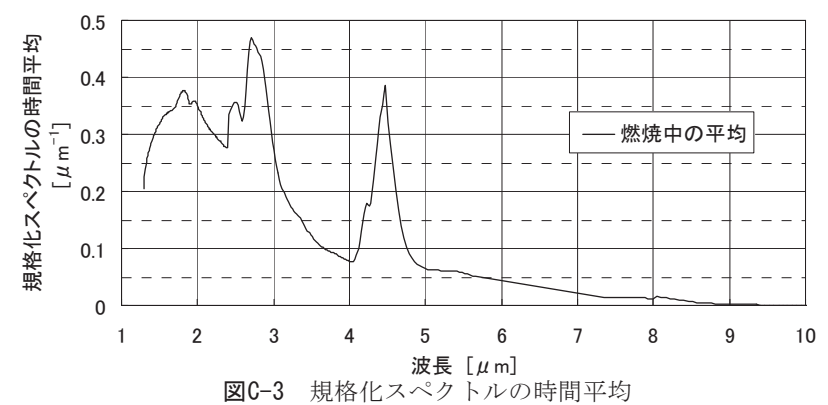

火炎のす寸によると考えられる黒体放射の形と、 $2.7 \mu \mathrm{m}$ と $4.5 \mu \mathrm{m}$ 付近に燃 焼ガスによると思われるピークが合成された形となった。以下ではこのスペ クトルを既知の関数にてフィッティングすることを検討する。

まず、燃焼ガスによるピーク部分を除き、黒体放射であるプランクの放射 則に最小二乗法を適用して温度を計算したところ、 $1647 \mathrm{~K}\left(=1374{ }^{\circ} \mathrm{C}\right)$ とい う温度が得られた。スペクトルから黒体放射を差し引き、2.7 $\mu \mathrm{m}$ と $4.5 \mu \mathrm{m}$ 付 近のピークを単一のガウス関数でフィッティングした。これらのフィッティ ング関数の和を図C-4に示す。

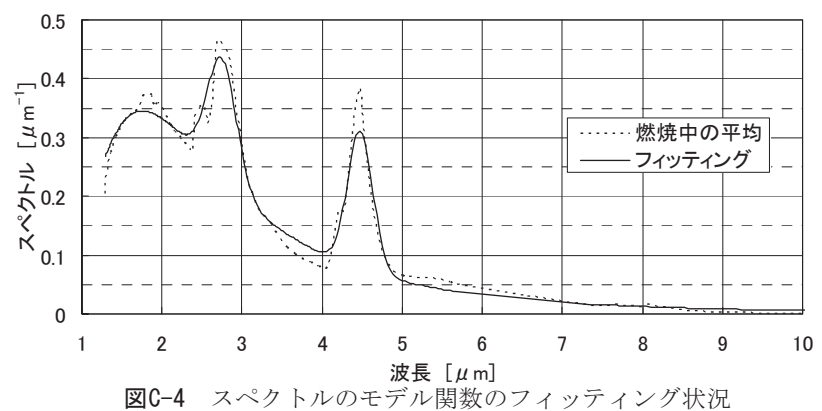

$2.7 \mu \mathrm{m}$ と $4.5 \mu \mathrm{m}$ のピークの高さや、ピーク前後の部分 $(2.4 \mu \mathrm{m} や 4.0 \mu \mathrm{m}$ 付近）で幾分の差異が見られるが、おおむね全体的な状況は再現していると 考えられる。なお、ピーク部分をローレンツ関数にてフィッティングする事 も試みたが、ガウス関数によるフィッティングの方が良かったため、ガウス 関数を用いることとした。

このフィッティング関数を再度全波長領域の積分值で正規化し、改めて木 材燃焼における規格化スペクトルの時間平均とする。

$$
\begin{aligned}
\bar{e}(\lambda)= & 1.989 \times 10^{-12} \times \frac{C_{1}}{\lambda^{5}} \frac{1}{\exp \left(C_{2} / \lambda T\right)-1} \\
& +0.1852 \times \exp \left(-\frac{\left(\lambda-\lambda_{1}\right)^{2}}{2 \sigma_{1}^{2}}\right)+0.2115 \times \exp \left(-\frac{\left(\lambda-\lambda_{2}\right)^{2}}{2 \sigma_{2}{ }^{2}}\right)
\end{aligned}
$$

ただし、 $C_{1}=3.74 \times 10^{-16} \mathrm{Wm}^{2} 、 C_{2}=1.438 \times 10^{-2} \mathrm{mK} 、 T=1647 \mathrm{~K} 、 \lambda_{1}=2.748 \times 10^{-6}$ $\mathrm{m} 、 \sigma_{1}=1.828 \times 10^{-7} \mathrm{~m} 、 \lambda_{2}=4.475 \times 10^{-6} \mathrm{~m} 、 \sigma_{2}=1.573 \times 10^{-7} \mathrm{~m}$ であり、 $\lambda$ 単位は $\mathrm{m} 、 \bar{e}(\lambda)$ の単位は $\mu \mathrm{m}^{-1}$ である。

\section{付録D}

Mie散乱理論を用いて得られる微分散乱断面積は、火炎からの放射のよう に入射電磁波が偏光していない場合、(D-1)式で表される11)。

$$
\frac{d \sigma_{s}}{d \Omega}=\frac{S_{1}(\theta) \cdot S_{1}^{*}(\theta)+S_{2}(\theta) \cdot S_{2}^{*}(\theta)}{2 k^{2}}
$$

ここでkは入射電磁波の波数であり、 $S_{1}$ と $S_{2}$ は散乱角 $\theta$ 方向の振幅関数である。 $S_{1}$ と $S_{2}$ は次の 2 式によって計算される。

$$
\begin{aligned}
& S_{1}=\sum_{n=1}^{\infty} \frac{2 n+1}{n(n+1)}\left[a_{n} \cdot \frac{P_{n}^{1}(\cos \theta)}{\sin \theta}+b_{n} \cdot \frac{d P_{n}^{1}(\cos \theta)}{d \theta}\right]_{(\mathrm{D}-2)} \\
& S_{2}=\sum_{n=1}^{\infty} \frac{2 n+1}{n(n+1)}\left[b_{n} \cdot \frac{P_{n}^{1}(\cos \theta)}{\sin \theta}+a_{n} \cdot \frac{d P_{n}^{1}(\cos \theta)}{d \theta}\right]
\end{aligned}
$$

なお、(D-2)式中の $a_{n}$ と $b_{n}$ の值は本文中 $(8) \sim(9)$ 式によって計算される值で
あり、 $P_{n}{ }^{1}$ はルジャンドルの陪関数を表す。

位相関数は微分散乱断面積を散乱断面積で規格化し、全立体角をかけたも のであり(D-3)式で表される。

$$
P(\theta)=\frac{4 \pi}{\sigma_{s}} \frac{d \sigma_{s}}{d \Omega}=\frac{2 \pi}{k^{2} \sigma_{s}}\left[\left|S_{1}(\theta)\right|^{2}+\left|S_{2}(\theta)\right|^{2}\right]
$$

上式を計算すると、例えば $2 \mu \mathrm{m}$ の波長においては図D-1の結果が得られ、 $\theta=0^{\circ}$ と $2.5^{\circ}$ の間においても $10^{5}$ 倍の差があることが分かった。この開きは波 長が長くなるほど小さくなるが、付録Cに示すスペクトルがほぼ収束する 10 $\mu \mathrm{m}$ においても103倍の差があった。
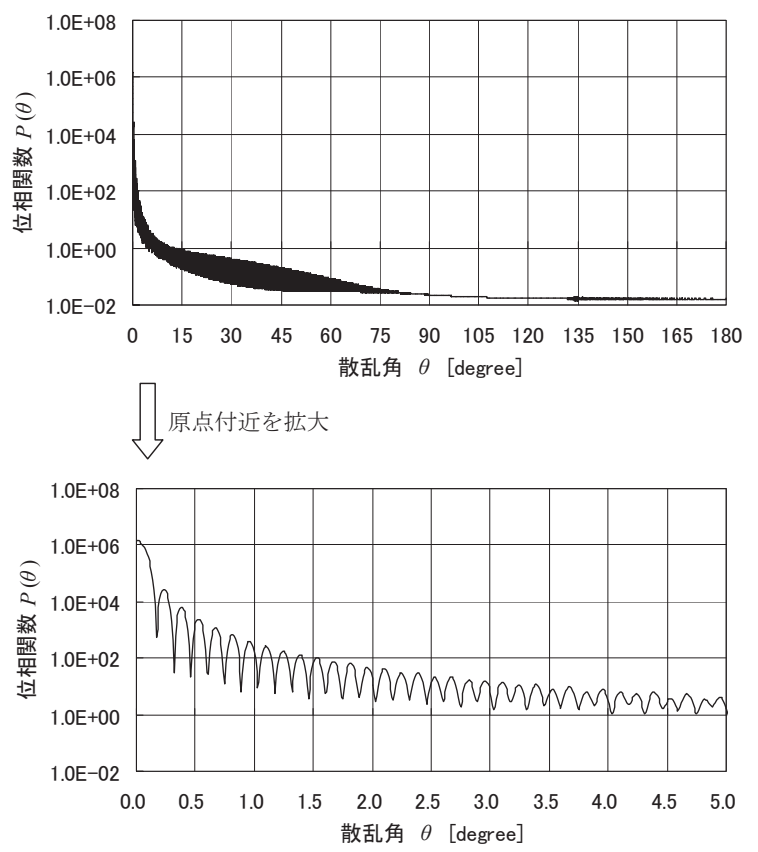

図D-1 波長 $2 \mu \mathrm{m}$ における位相関数の值

付録 $E$

ここでは、5.3の(15)式で定義した $B$ の值が 0 または非常に小さい值であるこ とを示す。なお、用いる記号は5.3で使用したものと同様とする。

付録Dのように、前方に極めて鋭いピークを持ち、それ以外の方向では小 さくなる散乱を、 $\delta$ 関数によって表すこととすると、(E-1)式の通りとなる。

$\bar{P}_{0}\left(\theta_{d}\right)=\bar{P}_{0}(0) \cdot \delta\left(\mu_{d}+1\right) \cdot \delta\left(\mu+\mu^{\prime}\right)$

これを(15)式に代入すると、

$$
\begin{aligned}
B & =\frac{1}{2 \pi} \int_{\mu=0}^{1} \int_{\mu^{\prime}=-1}^{0} \int_{\mu_{d}=\mu_{d, 0}}^{\mu_{d, 0}} \frac{\overline{P_{0}}(0) \cdot \delta\left(\mu_{d}+1\right) \cdot \delta\left(\mu+\mu^{\prime}\right)}{\sqrt{\left(1-\mu^{2}\right)\left(1-\mu^{\prime 2}\right)-\left(\mu_{d}-\mu \mu^{\prime}\right)^{2}}} \\
& \times d \mu_{d} d \mu^{\prime} d \mu \\
= & \frac{P_{0}(0)}{2 \pi} \int_{\mu=0}^{1} \int_{\mu^{\prime}=-1}^{0} \frac{\delta\left(\mu+\mu^{\prime}\right) \cdot d \mu^{\prime} d \mu}{\sqrt{\left(1-\mu^{2}\right)\left(1-\mu^{\prime 2}\right)-\left(-1-\mu \mu^{\prime}\right)^{2}}} \\
= & \frac{\bar{P}_{0}(0)}{2 \pi} \int_{0}^{1} \frac{d \mu}{\sqrt{\left(1-\mu^{2}\right)^{2}-\left(1-\mu^{2}\right)^{2}}} \\
= & \frac{\bar{P}_{0}(0)}{2 \pi} \int_{0}^{1} \frac{1}{0} d \mu
\end{aligned}
$$

被積分関数が発散するため、 $B$ が有限の值を取るためには $\bar{P}_{0}(0)$ が 0 又は十 分小さい值でなければならない。したがって、

$$
B=0 \text { 、または } B \cong 0
$$

